\title{
An Empirical Essay to Explain the Contrarian Profits in the Tunisian Stock Market: Behavioral Approach vs. Rational Approach
}

\author{
Ramzi Boussaidi ${ }^{1}$ \\ ${ }^{1}$ Faculty of Law, Economics and Management of Jendouba, Tunisia \\ Correspondence: Ramzi Boussaidi, Faculty of Law, Economics and Management of Jendouba, Avenue de \\ l’U.M.A, 8189, Tunisia. Tel: 216-25-090-060. E-mail: boussaidi.ramzi@yahoo.fr
}

Received: September 11, 2015

Accepted: October 13, $2015 \quad$ Online Published: November 25, 2015

doi:10.5539/ijef.v7n12p11

URL: http://dx.doi.org/10.5539/ijef.v7n12p11

\begin{abstract}
This paper aims to investigate the behavioral and the rational explanations for the contrarian profits in the Tunisian stock market. We use the CAPM and the three-factor model of Fama and French (1993, 1996) to examine the rational explanations including the market risk, the size effect and the book to market effect. Behavioral explanations include the overconfidence bias and the investor sentiment. We use the decomposition of the trading volume advanced by Chuang and Lee (2006) to extract the factor reflecting the investor overconfidence and the ARMS index to measure the investor sentiment. These two variables are included in the three-factor model of Fama and French $(1993,1996)$ in an attempt to confront the rational approach with the behavioral approach. The results indicate that the contrarian profits on the Tunisian stock market are explained by the market risk, the size effect and the Book to Market effect; and that once adjusted for these three risk factors, they disappear. However, only the factor reflecting overconfidence among the two behavioral factors seems to play a role in explaining these abnormal returns.
\end{abstract}

Keywords: contrarian profits, three-factor model, overconfidence, investor sentiment

\section{Introduction}

An extensive financial literature shows that stock prices exhibit a long-run mean reversion phenomenon characterized by a return reversal (e.g. De Bondt \& Thaler, 1985, 1987; Richards, 1997; Balvers, Wu, \& Gilliland, 2000, Chou, Chung, \& Wei, 2007; Akarim \& Sevim, 2013), a negative return autocorrelation (e.g. Fama \& French, 1988, Bali, Demirtas, \& Levy, 2008; Mukherji, 2011) and a cointegration relationship between the stock prices and their fundamental value (e.g. Campbell \& Shiller, 1987, Nasseh \& Strauss, 2004; Kapitanios, Shin, \& Snell, 2006, McMillan, 2007, 2009; Kanas, 2005). As a result of these three characteristics, it has been shown that this phenomenon generates a specific investment style called "contrarian strategy" consisting in selling stocks that have had a good performance and purchasing stocks that have had a poor performance on a past period and reverse these positions after a long period of, for example, three years. The sources of the profits generated by such strategy are still the subject of extensive debate. This debate, boosted by the emergence of behavioral finance, leads to strong conflicting interpretations of the existence and the explanatory theories of this anomaly. As a consequence, two competing approaches emerged: the behavioral approach and the rational approach.

The behavioral approach or the behavioral finance attributes this anomaly to the investors' overreaction to new information, a hypothesis mainly defended by De Bondt and Thaler (1985, 1987), Lakonishok, Shleifer, and Vishny (1994), Barberis, Shleifer, and Vishny (1998), Daniel, Hirshleifer, and Subrahmanyam (1998) and Shiller (2000). This new field of research, which is constantly developing, is mainly based on human psychology that identifies several biases that may affect the way people process information and make decisions under uncertainty. Even this approach suffers a lack of consensus on the explanation of the overreaction hypothesis. Some researchers explain the overreaction through the representativeness heuristic (Barberis et al., 1998; Bloomfield \& Hales, 2002, Frieder, 2008; Kaestner, 2006; Shefrin, 2008; Alwathainani, 2012; etc.); others explain it through the overconfidence bias (Daniel et al., 1998; Shiller, 2000; Gervais \& Odean, 2001; Chuang and Lee, 2006; Chuang \& Susmel, 2011; Chou \& Wang, 2011; etc.).

The advocators of the second approach, having always Eugene F. Fama as leader, suggest that we can explain this anomaly in a context of rationality and mainly attribute it to the market risk (Fama \& French, 1993, 1996; 
Galariotis, Holmes, \& Ma, 2007, and Chou et al., 2007), the size effect (Zarowin, 1990, Eraker, 2008), the January effect (Jegadeesh, 1991, Gangopadhyay \& Reinganum, 1996) or the book-to-market effect (Fama \& French, 1996; and Nagel, 2001).

Generally investigated in developed financial markets, the profitability of the contrarian strategy remains less explored in the context of underdeveloped financial markets. This is why it seems important in this research, to contribute to this debate by studying the profitability of the contrarian strategy in the Tunisian context. We try to know whether contrarian profits are due to rational or behavioral factors.

Our main purpose is to confront, through a summary empirical investigation, the behavioral approach supporting the overreaction hypothesis explained by the overconfidence bias and the representativeness heuristic, with the rational approach based on the market risk, the size effect and the book-to-market effect. We especially try to know whether overconfidence and investor sentiment explain the long-run return reversal and the contrarian profits. To do so, the factors that are supposed to explain the contrarian profits are included in a single model. Furthermore, studies that examined the profitability of the contrarian strategy did not investigate the direct impact of the overconfidence and the investor sentiment on the contrarian profits. This paper attempts to examine this link. This essay, then, does not only help distinguish between the two approaches, but it also allows us to explore the direct relationship between the overconfidence and the contrarian profits.

This paper is organized as follows. The second section discusses the main rational and behavioral sources of the contrarian profits. The third section empirically examines which of these sources contribute to the explanation of the contrarian profits in the Tunisian Stock market. The last section concludes the paper.

\section{Literature Review}

\subsection{The Rational Approach}

Main rational explanations of the contrarian profits include the size effect, the January effect, the book to market effect and the market risk. The size effect was advanced by some authors as a possible explanation to the contrarian profits in the sense that the losers tend to generate a better performance than the winners because they are relatively small stocks. Zarowin (1990) showed that the return reversal initiated by De Bondt and Thaler (1985) in the US market is explained by the size effect. He noticed that for 13 out of the 17 portfolio rank periods, the average market value of equity of the losers is lower than that of the winners. By regressing the cumulative abnormal returns generated during the holding period on the size and the cumulative abnormal returns of the rank period, he further found that the contrarian profits are explained by the size. In the Australian market, Gaunt (2000) found results that confirm those of Zarowin (1990). He found that on average $74.1 \%$ of the firms composing the loser portfolio are small and $41.5 \%$ of the firms composing the winner portfolio are big. Using the 25 portfolios formed by Fama and French (1993 and 1996), Eraker (2008) showed through a generalization of the univariate model of Fama and French (1988) and Poterba and Summers (1988), that the long-run return reversal in the U.S Market over the period 1927-2004 is largely due to the size effect. By adopting size and book to market sorted portfolio, he found that portfolios of small firms display about three times the amount of mean reversion than for large firms. However, Galariotis et al. (2007) argue that the size effect does not sufficiently explain the profitability of the contrarian strategies. They found that although the portfolio of small stocks outperforms the portfolio of big stocks, this outperformance decreases monotonically with the holding period; and since the contrarian profits are concentrated in long holding periods, the authors suggested that they cannot be explained only by the firm size.

Other researchers attribute the contrarian profits to the January effect. It was initially observed by De Bondt and Thaler $(1985,1987)$ who found that the return reversal is accompanied by a seasonality in January indicating higher excess returns in this month. De Bondt and Thaler (1987) found that the excess returns of January are negatively correlated with the excess returns of previous December especially for the winners. They interpreted this phenomenon as a tax effect. Zarowin (1990) found that the contrarian profits are mainly generated in this month. Jegadeesh (1991) and Gangopadhyay and Reinganum (1996) also found that the mean reversion is a January effect in the US and in the UK markets. On the London Stock Exchange, Galariotis et al. (2007) found that the January effect does not explain the profitability of the contrarian strategies. By excluding the returns of January, these strategies remain significantly profitable and grow even in number. They increase from 9 to 14 dependent on the length of the formation and the holding periods. Similar results were recently found by Wu and Li (2011) for a sample of 1673 firms listed on the London Stock Exchange over the period 1974-2009. Mun, Vasconcellos and Kish (2001) showed, also, that the contrarian profits in the US and Canadian markets cannot be explained by the January effect.

One of the explanations for the contrarian profits that have received considerable attention in the empirical 
studies is the market risk. The hypothesis tested by this approach is generally whether the loser portfolios are riskier than the winners. If this is the case, then the contrarian strategies profitability should not be considered as an anomaly, and it is, therefore, consistent with the efficient market hypothesis. However, if these strategies generate significant risk-adjusted profits, then these profits are considered abnormal. To adjust the contrarian profits for risk, the empirical studies use the Capital Asset Pricing Model created by Sharpe (1964), Lintner (1965) and Mossin (1966) or the three-factor model of Fama and French (1993, 1996). Chan (1988) and Ball and Kothari (1989) adopted the CAPM equation and showed that the reversal of the extreme portfolios can be attributed to the risk changes from the formation period to the holding period. Adopting a similar approach, Gunaratne and Yonesawa (1997) found, contrary to the authors, that the risk measured by the beta of the CAPM does not explain the contrarian profits on the Tokyo Stock Exchange for the period 1955-1990 in support of the overreaction hypothesis. Fama and French (1996) found that the portfolio returns tend to demonstrate a momentum after a 12-month formation period and a reversal after 48 and 60 months. When these returns are adjusted for size effect, book to market effect along with the market risk, those corresponding to 12-month-formation period still show momentum, while those corresponding to 48 and 60 month-formation periods disappear. Chou et al. (2007) reconsidered the model of Fama and French $(1993,1996)$ and concluded that the contrarian profits are not due to forecast errors as stated by the behavioral models. Rather, it's the component of the firms' specific error that helps explain the contrarian profits. This implies that the three-factor can explain the contrarian profits in the Japanese stock market. Galariotis et al. (2007) found that when the contrarian profits are adjusted for market risk using the CAPM, the number of contrarian strategies significantly increased from 9 to 11, indicating that the return adjustment for the market movements does not explain the contrarian profits. However, using the three-factor model makes the contrarian profits disappear indicating that this model fully explains these profits. Using index data of 16 countries, Richards (1997) showed that the excess returns of the loser portfolio do not reward taking an additional risk, as the latter is measured by the standard deviation of returns, the covariance with risk factors such as the world index and the exchange rate risk, or the performance of losers in various states of the world.

\subsection{The Behavioral Approach}

The behavioral approach explains the contrarian profits by the investor overreaction caused by the overconfidence bias and the representativeness heuristic. Motivated by psychology and experimental studies, Wang (1998), Kyle and Wang (1997), Odean (1998) and, Daniel et al. (1998) have modelled the investors' overconfidence as an overestimation of the precision of their private information. To reconcile the underreaction and the overreaction phenomena, Daniel et al. (1998), for example, distinguished between two states of confidence: static confidence and dynamic confidence. Static confidence is the confidence that the investors initially exhibit when they overestimate their private signals. These investors overreact to these signals causing a price deviation from rational level. With the arrival of public information, such a deviation is partially corrected. Dynamic confidence is induced by the self-attribution bias that arises when a public signal confirms the private signal initially generated by the investor. The public information further stimulates the investor overreaction and therefore increases price deviation from rational level. The repetitive public information announcement causes a gradual correction of the initial overreaction and, therefore, a price mean reversion to fundamentals value or, similarly, a return reversal. Chuang and Lee (2006) empirically tested this hypothesis on U.S. data covering the period from 1963 to 2001 with a weekly frequency and found that prices strongly overreact to private information shock and underreact to public information shock. Similar results were found by Darrat, Zhong and Cheng (2007) using intraday frequency.

Barberis et al. (1998), however, used the representativeness heuristic to model the investor overreaction. They suggest that when investors realize that a firm has a history of a good performance sustained, for example, by an earnings or sales growth, they deduce that such a history is representative of a good performance. They become overly optimistic about the future perspectives of the firms, and thus extrapolate the past performance far into the future causing an overvaluation of the firm stock price. They will be disappointed later once subsequent news announcements do not confirm their prior optimism, which leads to a price decrease below its fundamental value and, then, to poor returns. The overreaction hypothesis implies that the overweighting of bad (good) information leading to a decrease (increase) in prices below (above) their fundamental value is corrected in subsequent period. Frieder (2008) has provided empirical evidence supporting this hypothesis in the US market using a series of earnings surprises as indicators of past performance. She found that investors buy significantly more stocks after a series of positive surprises, followed subsequently by a stock underperformance. Using series of similar past consecutive returns, Alwathainani (2012) found that the loser portfolio outperforms the winner portfolio 2, 3, 4 and 5 years later. 


\section{Empirical Analysis}

The purpose of this empirical investigation is to confront the behavioral approach with the rational approach in an attempt to explain the contrarian profits in the Tunisian stock market. The behavioral approach is based on the overreaction hypothesis explained by the representativeness heuristic and the overconfidence bias. The rational approach, as modeled by Fama and French $(1993,1996)$, is based on the market risk, the size effect and the Book to Market effect.

\subsection{Models}

To examine the sources of the contrarian profits, we regress the returns of the winner, the loser and the arbitrage portfolio on risk and "behavioral" factors. We start with the CAPM to explore the contribution of the market risk to the explanation of the contrarian profits; we estimate then the three-factor model of Fama and French (1993, 1996) to explore the effect of the other risk factors such as the size effect and the Book to Market effect. Finally, we add our two behavioral or psychological factors to the three-factor model: a factor reflecting the investor optimism or pessimism and another one reflecting the investor overconfidence.

\subsubsection{Adjusting the Contrarian Returns for Market Risk: The CAPM}

We use the CAPM to adjust the returns generated by the loser portfolio, the winner portfolio and the contrarian strategy for market risk as follows:

$$
R_{p, t}-R_{f, t}=\alpha+\beta\left(R_{m, t}-R_{f, t}\right)+\varepsilon_{t}
$$

Where $R_{p, t}$ is the monthly return of the loser portfolio $R_{L}$, the winner portfolio $R_{W}$, or the arbitrage portfolio $R_{L-W}$. The arbitrage portfolio consists of a long position on the loser and a short position on the winner (Loser minus winner). $R_{m}$ is the monthly market portfolio return; $R_{f, t}$ is the risk-free rate. $\alpha$ and $\beta$ are parameters to estimate. For the regression corresponding to the arbitrage portfolio returns, we exclude the risk-free rate $R_{f, t}$ from the left side of the equation to make its excess returns interpreted as returns on zero-investment strategies. The constant $\alpha$ represents the excess return adjusted for the market risk.

If the contrarian profits are explained by the market risk, then we must find that the loser portfolio is riskier than the winner portfolio $\left(\beta_{L}>\beta_{W}\right)$ and the abnormal return given by $\alpha$ is insignificant. If not, we consider that the market risk (beta) does not sufficiently explain the contrarian returns and, then, we should add other risk factors; or they are due to the investors' overreaction.

\subsubsection{Adjusting the Contrarian Returns for the Three Factors of Fama and French $(1993,1996)$}

Since the CAPM has failed to explain many anomalies, Fama and French $(1992,1993,1996)$ developed a three-factor model reflecting, other than the market risk calculated by the $\beta$, a risk related to the size of firms and a risk related to the book-to-market effect. Empirically, this model has shown a good performance to explain the abnormal returns generated by these anomalies except the abnormal returns generated by the momentum effect. Fama and French (1992) concluded that if the stocks are rationally evaluated, then their risk is multidimensional: One dimension of risk is proxied by the size, and another dimension is proxied by the Book to Market ratio. These two variables tend to reflect returns sensitivity to common risk factors shared by the stocks, which makes of them undiversifiable risk factors. Fama and French (1993) found that this model shows, empirically, a good performance to explain returns. This performance is justified by the fact that portfolios constructed to reflect the risk factors related to the size and Book to Market significantly detect the common variation in returns, and the estimated constant is always close to zero. Recently, Baek and Bilson (2014) reported similar results for the period 1963-2010 even for financial firms, often excluded when estimating this model.

We use the model of Fama and French $(1993,1996)$ to adjust the returns of the loser, the winner, and the arbitrage portfolios for the firm size and the Book to Market equity in addition to the market risk. This model is written as follows:

$$
R_{p, t}-R_{f, t}=\alpha+\beta\left(R_{m, t}-R_{f, t}\right)+s R_{S M B, t}+h R_{H M L, t}+\varepsilon_{t}
$$

Where, $R_{p, t}$ is the monthly return of the loser portfolio $R_{L}$, the winner portfolio $R_{W}$ or the loser minus winner portfolio $R_{L-W}$ (in the case of $R_{L-W}$ we exclude $R_{f}$ from the left side of the regression); $R_{m, t}$ is the portfolio market return in month $t ; R_{f, t}$ is the risk-free interest rate in month $t$;

$R_{S M B, t}$ is the difference, in month $t$, between the return on the portfolio of small stocks and the return on portfolio of large stocks (Small Minus Big);

$R_{H M L, t}$ is the difference, in month $t$, between the return on portfolio of high Book to Market stocks and the 
return on portfolio of low Book to Market stocks (High Minus Low).

The two factors $R_{S M B}$ and $R_{H M L}$ represent the risk premiums related to the size and the Book to Market, respectively. They are calculated as in Fama and French $(1993,1996)$. Therefore, this model allows us to examine whether the profitability of the contrarian strategy is a compensation for these two risk factors in addition to the market factor.

\subsubsection{Do Behavioral Factors Explain the Contrarian Profits?}

To determine whether the profitability of the contrarian strategy is due to the investors' overreaction as a result of the overconfidence bias and the investor sentiment, we add to the preceding model two behavioral factors that reflect this overreaction: a sentiment index reflecting the investors' optimism or pessimism and an index reflecting the investors' overconfidence.

The factor reflecting the overconfidence bias is extracted from the decomposition of Chuang and Lee (2006). The validity of the decomposition depends on the existence of the overconfidence bias. That's why we should check the presence of such a bias in the Tunisian market before extracting this factor. It will be denoted "CONF".

It has been shown that the sentiment indicators are generally considered as contrarian indicators in the sense that a sentiment of optimism is associated with low future returns while a sentiment of pessimism is associated with high future returns (Brown \& Cliff, 2005; Baker \& Wurgler, 2006; Lemmon \& Portniaguina, 2006; Schmeling, 2009; etc.). This is explained by the fact that overoptimistic (pessimistic) investors tend to cause an overvaluation (undervaluation) of the stocks which is corrected later when prices revert back to their fundamental value. We add then a sentiment factor in our model in an attempt to explore the behavioral explanation for the contrarian profits. Furthermore, in their analysis of the impact of the representativeness heuristic on the investor overreaction Barberis et al. (1998) considered the optimism or the pessimism concept. As there is not yet a proxy for the representativeness heuristic, the sentiment index measuring the investor optimism or pessimism can be used to test the impact of this bias on the contrarian strategy. In our study we use the ARMS index as an indicator of the sentiment index that reflects the excessive optimism or pessimism.

Finally, the obtained model can be written as follows:

$$
R_{p, t}-R_{f, t}=\alpha+\beta\left(R_{m, t}-R_{f, t}\right)+s R_{S M B, t}+h R_{H M L, t}+m A R M S_{t}+f C O N F_{t}+\varepsilon_{t}
$$

We proceed next to the calculation of the variables used in the three models. The calculation of the returns of the winner, the returns of the loser, the contrarian profits and the three risk premium requires the formation of some portfolios.

\subsection{Portfolios' Formation and Calculation of the Variables}

\subsubsection{The Fama and French $(1993,1996)$ Factors: $R_{S M B}$ and $R_{H M L}$}

First, at the end of June of each year of the period 1990-2013, all firms listed on the Tunisian Stock market (including newly listed firms during this period) are ranked based on market equity (end of June stock price times shares outstanding), and then assigned to two groups: $50 \%$ of the firms having the lowest market equity (denoted $S$ ) and $50 \%$ having the highest market equity (denoted $B$ ). Both groups are composed of an equal number of firms. Similarly to Fama and French $(1992,1993,1996)$ we use the market value of June of the year $\mathrm{N}$ to measure the size of the firm.

Second, we form two groups of firms based on book-to-market equity: the first group consists of the firms having the lowest $\mathrm{B} / \mathrm{M}$ (denoted $L$ ) and the second one, the highest $\mathrm{B} / \mathrm{M}$ (denoted $H$ ). This ratio is calculated by dividing the book value of equity of the year N-1 by the market value of equity at the end of December of year N-1. Similarly to Fama and French $(1992,1993,1996)$ we use the end of year N-1 market value to get a book value in the numerator aligned with the market value in the denominator.

Finally, we construct four portfolios from the intersection of the two preceding portfolios ( $2 \times 2$ portfolios): S/L, $\mathrm{S} / \mathrm{B}, \mathrm{B} / \mathrm{L}, \mathrm{B} / \mathrm{H}$. For example, the portfolio $\mathrm{S} / \mathrm{L}$ is the portfolio of the firms having simultaneously the lowest market equity (S) and the lowest book-to-market equity (L); i.e. firms in group 1 formed based on the size and those in group 1 formed based on the book-to-market equity. In the American context, Fama and French (1993) formed $2 \times 3$ portfolios from the intersection of two portfolios formed based on the size and three portfolios formed based on the B/M. Instead, Fama and French (1996) have used 5x5 portfolios after constructing 5 portfolios based on each criterion. To adapt the methodology of Fama and French $(1993,1996)$ to the Tunisian context, it seems appropriate to form $2 \times 2$ portfolios because the number of stocks is relatively low compared to the US context. 
We calculate then the monthly value-weighted returns of the 4 portfolios from July of year $\mathrm{N}$ to June of year $\mathrm{N}+1$, and reconstruct the portfolios in June of year $\mathrm{N}+1$. Returns are calculated from July $\mathrm{N}$ to ensure that the book value of equity of year $\mathrm{N}-1$, used in the calculation of the book to market ratio, is known at that time. In fact, the six-month gap between the end of the year N-1 and the releasing time of the annual reports to the stock market is necessary to make these reports publically available. This explains why we should match the end of year N-1-accounting data with returns from July of year $\mathrm{N}$ to June of year $\mathrm{N}+1$. Thereafter, we compute the returns reflecting the risk factors related to the size and the Book to Market. The $R_{S M B}$ return is the difference, each month, between the average returns of the two portfolios comprising small stocks $(\mathrm{S} / \mathrm{L}$ and $\mathrm{S} / \mathrm{H})$ and the average returns of the two portfolios comprising big stocks (portfolios $\mathrm{B} / \mathrm{L}$ and $\mathrm{B} / \mathrm{H}$ ). The two components of the obtained SMB portfolio are returns of the portfolio with small and big stocks with almost the same weighted-average book to market ratio. $R_{S M B}$ is calculated, according to Fama and French (1993), in this way in spirit to isolate the difference between the small cap stock returns and the large cap stock returns from the influence of the book-to-market equity. Therefore, the $R_{S M B}$ premium reflects the risk factor related to the firms' size.

$R_{H M L}$ is the difference, each month, between the equal-weighted average returns of the two portfolios having high book-to-market equity (portfolios $\mathrm{S} / \mathrm{H}$ and $\mathrm{B} / \mathrm{H}$ ) and equal-weighted average returns of the two portfolios having low book-to-market equity (portfolios S/L and B/L). The two components of the obtained HML portfolio are returns of the portfolio with high book-to-market equity and low book-to-market equity with almost the same size. Thus, the difference between the two returns is largely independent of the size factor and takes account of the different behavior of the firms' returns having low and high book to market ratio. The premium $R_{H M L}$ therefore reflects the risk factor related to the book to market.

It is possible to check the relevance of this methodology by calculating, according to Fama and French (1993), the correlation between the returns corresponding to these two factors. We find that the correlation between $R_{H M L}$ and $R_{S M B}$ is equal to -0.10 , indicating a weak relationship between the two variables. Such a correlation supports the use of this methodology in the Tunisian context.

The market risk factor is calculated by the market return in excess of the risk-free interest rate $\left(R_{m}-R_{f}\right)$ where $R_{m}$ is the equal-weighted returns, each month, of the stocks composing the $2 \times 2$ portfolios formed based on the size and the book-to- market equity. $R_{f}$ is approximated, as in Gunaratne and Yonesawa (1997), by the Money Market Rate.

\subsubsection{Returns of the Loser and the Winner Portfolios}

At the end of each month $t$ over the period 1991-2013, firms are ranked based on the average past returns calculated for a formation period of 24, 36 and 48 months with and without skipping one year after the formation date. We use the interval $[t-x, t-y]$ to denote the formation period. For example, for a 24 month-formation period, if we skip 12 months after the formation date then the formation period will be [t-36,t-13]; if not, it will be $[t-24, t-1]$. The stocks are, then, allocated to three groups (Note 1). The group consisting of stocks having experienced the highest returns is labeled the winner portfolio $(W)$, and the group of stocks having experienced the lowest returns is labeled the loser portfolio $(L)$. If the number of stocks is not perfectly divisible by 3 , it will be rounded to the nearest integer to ensure the winner portfolio and the loser portfolio have the same number of stocks. The two portfolios are reconstructed each month and the return on each one of them is the equal-weighted returns of the $n$ stocks composing it:

$$
R_{p, t}=\frac{1}{n} \sum_{i=1}^{n} R_{i, t} ; p=W \text { or } L
$$

Where $R_{i, t}$ is the return on stock $i$ in month $t$ calculated as the logarithm of the closing price of month $t$ to the closing price of the preceding month:

$$
R_{i, t}=\operatorname{Ln}\left(\frac{P_{i, t}}{P_{i, t-1}}\right)
$$

\subsubsection{The Sentiment Indicator: ARMS Index}

The ARMS Index in month $t$ is defined as the ratio of the number of advancing stocks to the number of declining stocks standardized by their respective trading volumes expressed in number of shares traded. 


$$
A R M S_{t}=\frac{N a d v_{t} / V a d v_{t}}{N d e c_{t} / V d e c_{t}}=\frac{V d e c_{t} / N d e c_{t}}{V a d v_{t} / N a d v_{t}}
$$

Where $N a d v$ is the number of advancing stocks, Vadv is the trading volume of advancing stocks, Ndec is the number of declining stocks, and Vdec is the trading volume of declining stocks.

A stock is considered as an advancing (declining) one if its monthly return calculated between the closing prices of the end of months $t-1$ and $t$ is positive (negative). The trading volume of advancing (declining) stocks is the sum of the number of shares traded of the firms showing a stock price increase (decrease). The monthly trading volume of each firm is the sum of its shares traded during the month.

As shown by the formula (6), the ARMS index can be written as the ratio of volume per declining stock to the volume per advancing stock. It indicates that when the average trading volume of declining stocks exceeds the average trading volume of advancing stocks (i.e. ARMS $>1$ ), the market is described as "oversold", which reflects a sentiment of pessimism. However, if the average trading volume of rising stocks exceeds the average trading volume of decreasing stocks $(\mathrm{ARMS}<1)$, the market is described as "overbought" indicating a sentiment of optimism.

\subsubsection{The Overconfidence}

Some psychology and experimental studies have shown that people assign the success generated through random events to their talents and failures to external factors, a bias called self-attribution (Miller \& Ross, 1975, Langer \& Roth, 1975; Schlenker \& Miller, 1977; Greenwald, 1980; Wolosin, Sherman,\& Till, 1973). This bias represents one of the facets of the overconfidence bias. Motivated by these studies, several financial studies show that investors exhibit such a bias, wherein the overconfident investors mistakenly attribute market gains to their ability to select winner stocks and to correctly process information; and therefore trade excessively in the subsequent period after observing high market returns. This effect results in one-direction causal relationship from past returns to trading volume (Odean, 1998; Darrat et al., 2007; Chuang \& Lee, 2006; Griffin, Nardari, \& Stulz, 2007; Statman, Thorley, \& Vorkink, 2006; Chuang \& Susmel, 2011; and Glaser \& Weber, 2007, 2009). However, this assumption does not necessarily imply that overconfidence is the only source of excessive trading. To distinguish between the effect of overconfidence and other factors on trading volume, Chuang and Lee (2006) decomposed the trading volume into two components as follows:

$$
\begin{aligned}
V_{t}=\lambda+\sum_{j=1}^{p} \theta_{j} R_{t-j}+\varepsilon_{t} & =\left[\sum_{j=1}^{p} \theta_{j} R_{t-j}\right]+\left[\lambda+\varepsilon_{t}\right] \\
& =\text { OVER }_{t}+\text { NONOVER }_{t}
\end{aligned}
$$

Where the constant and the residual terms represent the component of the volume not related to the investor overconfidence effect (NONOVER), and the difference between the trading volume and this component represents the trading volume resulting from the behavior of the overconfident investors after observing past returns $(O V E R)$.

In our study, the indicator reflecting the investor overconfidence is extracted, according to Chuang and Lee (2006), from the previous equation after, of course, checking the one-direction causal relationship from past returns to trading volume giving evidence of the existence of a self-attribution bias. This relationship will be examined by considering the following Vector Autoregressive model:

$$
\left\{\begin{array}{c}
V_{t}=\alpha_{1}+\sum_{j=1}^{p} \beta_{1 j} V_{t-j}+\sum_{j=1}^{p} \theta_{1 j} R_{t-j}+\varepsilon_{1 t} \\
R_{t}=\alpha_{2}+\sum_{j=1}^{p} \beta_{2 j} V_{t-j}+\sum_{j=1}^{p} \theta_{2 j} R_{t-j}+\varepsilon_{2 t}
\end{array}\right.
$$

Where $V$ is the market trading volume and $R$ is the market return. To calculate the market trading volume we use the turnover as in Lo and Wang (2000), Chuang and Lee (2006), Statman et al. (2006) and Griffin et al. (2007). The turnover of a stock $i$ is the ratio of the number of shares traded to the number of shares outstanding. The market turnover at time $t$ is calculated as in Lo and Wang (2000), by the value-weighted turnover of stocks in the sample: 


$$
\text { Turnover }_{t}=\sum_{i=1}^{n}\left(\omega_{i, t} \times \text { Turnover }_{i, t}\right)
$$

Where turnover $_{t}$ is the value-weighted turnover of stocks in the sample in month $t$; turnover ${ }_{i t}$ is the turnover of stock $i$; and $\omega_{i, t}$ is the weight of stock $i$ in the sample calculated by the ratio of market value of equity at the end of month $t$ to the sum of the market value of equity of the $n$ stocks in the sample.

\subsection{Data Analysis}

Our data consist of the end of the month stock prices, the number of shares outstanding, the number of shares traded (daily trading volume), the book value of equity of all the firms listed on the Tunisian stock market over the period January 1991 - December 2013 and the Money Market Rate (MMR). For the stock price data, we go back to January 1986 to calculate the past stock returns necessary for the formation period prior to January 1991-formation date. The book value of equity data are hand-collected from corporate balance sheets published in the "bulletin of the financial market council" and the "bulletin of the Tunis stock Exchange". MMR is taken from the Tunisian Central Bank website. The MMR is used, as in Gunaratne and Yonesawa (1997), as a proxy for the risk-free rate $\left(R_{f}\right)$.

Our sample is rebalanced to include newly listed firms in order to obtain results reflecting the whole market. The selected firms are those for which the above stock market and accounting data are available. Our final rebalanced sample consists of 16 firms in January 1991, gradually expandingto 48 firms in December 2013. To check the robustness of our results, we consider the sub-period 2000-2013 which is characterized by high number of listed firms relative to the nineties.

Descriptive statistics for the full sample period 1991-2013 without skipping 12 months after the portfolio formation date are displayed in table 1 (descriptive statistics if we skip 12 months and those corresponding to the sub-period 2000-2013 are available on request). We note that the loser portfolio generates on average a positive return while the winner generates on average a negative return irrespective of the formation period. For example, for 36 month-formation period without skipping one year after the formation date, the average return of the loser portfolio is $0.6 \%$ while the average return of the winner is $-0.1 \%$. This indicates a reversal effect of the past returns in support of the mean reversion hypothesis. The standard deviation of the loser portfolio is slightly lower than that of the winner portfolio and it is in some cases very close to each other, indicating that the loser is not riskier than the winner. This implies that the outperformance of the loser relative to the winner is not due to the fact that the loser is riskier than the winner. This statistic analysis seems to be in favor of the overreaction hypothesis as an explanation for the contrarian profits. This preliminary analysis holds if we skip 12 months after the formation date and for the sub-period 2000-2013.

Table 1. Descriptive statistics for full sample period 1991-2013

\begin{tabular}{lccccccccccccc}
\hline & $R_{L 24}$ & $R_{W 24}$ & $R_{L 36}$ & $R_{W 36}$ & $R_{L 48}$ & $R_{W 48}$ & $R_{m}$ & $R_{f}$ & $S M B$ & $H M L$ & $V$ & ARMS & CONF \\
\hline Mean & 0.004 & -0.001 & 0.006 & -0.001 & 0.007 & -0.003 & 0.004 & 0.005 & 0.007 & 0.007 & 0.010 & 1.362 & 0.000 \\
Median & 0.002 & 0.002 & 0.002 & 0.002 & 0.001 & 0.004 & 0.002 & 0.005 & 0.005 & 0.004 & 0.008 & 0.745 & 0.000 \\
Max & 0.221 & 0.205 & 0.197 & 0.195 & 0.265 & 0.171 & 0.230 & 0.009 & 0.215 & 0.219 & 0.038 & 62.211 & 0.006 \\
Min & -0.166 & -0.283 & -0.157 & -0.236 & -0.143 & -0.236 & -0.236 & 0.003 & -0.219 & -0.169 & 0.001 & 0.020 & -0.007 \\
Std. Dev. & 0.047 & 0.053 & 0.047 & 0.050 & 0.046 & 0.053 & 0.052 & 0.002 & 0.049 & 0.046 & 0.006 & 4.187 & 0.002 \\
Skewness & 0.548 & -0.835 & 0.624 & -0.786 & 1.264 & -1.054 & -0.189 & 1.005 & 0.078 & 0.514 & 1.219 & 12.16 & -0.178 \\
Kurtosis & 6.247 & 8.202 & 5.369 & 7.060 & 8.171 & 6.542 & 8.083 & 2.921 & 5.867 & 6.692 & 5.034 & 168.8 & 5.544 \\
JB & 135.0 & 343.2 & 82.48 & 218.0 & 381.0 & 195.3 & 298.8 & 46.50 & 94.82 & 168.8 & 115.9 & 319744 & 75.05 \\
Prob. & 0.000 & 0.000 & 0.000 & 0.000 & 0.000 & 0.000 & 0.000 & 0.000 & 0.000 & 0.000 & 0.000 & 0.000 & 0.000 \\
\hline
\end{tabular}

\subsection{Results and Discussion}

\subsubsection{Adjusting Contrarian Profits for the Market Risk: the CAPM}

The results of the OLS estimation of the model (1) for the full-sample period 1991-2013 are displayed in table 2. During the test period subsequent to a 24 -month rank period $[t-24, t-1]$, the estimated beta of the loser portfolio is 0.1708 lower than that of the winner portfolio indicating that the loser portfolio is less risky than the winner portfolio. This difference is significantly different from zero $\left(t_{\beta, L-W}=-2.534\right)$.

Furthermore, the monthly abnormal return of the winner portfolio is negative $(\alpha=-0.50 \%)$ and significant at the 
$5 \%$ level $\left(t_{\alpha, W}=-2.170\right)$ indicating a statistically significant reversal of the portfolio. The excess return of the loser portfolio, although negative $(-0.08 \%)$, remains higher than that of the winner portfolio but not statistically significant $\left(t_{\alpha, L}=-0.366\right)$. The contrarian profits are positive $\left(\alpha_{L-W}=0.41 \%\right)$ but not significant $\left(t_{\alpha, L-W}=1.195\right)$. The non-significance of the contrarian profits is probably due to the non reversal of the loser portfolio.

After a formation period of 36 months [t-36, t-1], the loser portfolio remains less risky than the winner one in the sense that the beta of the loser is less than the beta of the winner. However, the arbitrage portfolio does not show sensitivity to the market risk because the $\beta$ is not significant $\left(t_{\beta, L-W}=-0.768\right)$. The excess returns of the loser portfolio is positive but not statistically significant indicating no significant reversal of this portfolio $(\alpha=0.0020$, $\left.t_{\alpha}=0.949\right)$. The winner portfolio recorded a significant reversal $\left(\alpha=-0.0051, t_{\alpha}=2306\right)$. The reversal of the two portfolios generates a significant gain of $0.72 \%\left(t_{\alpha, L-W}=2.284\right)$. Similar results were obtained for a 48-month formation period [t-48, $\mathrm{t}-1]$. If we skip 12 months after the date of the formation period $([t-36, t-13],[t-48, t-13]$ and $[t-60, t-13])$, we obtain the same results, except that for the last formation period, the excess return of the arbitrage portfolio is not significant.

To check the robustness of our results, we replicated our methodology for the sub-period January 2000-December 2013 (results available on request). The loser portfolio remains less risky than the winner portfolio and the reversal is not usually significant. In addition, the contrarian profits found above disappear once they are adjusted for the market risk. For example, for the formation period [t-36, t-1] we found $\alpha_{L-W}=0.47 \%$ $\left(t_{a, L-W}=1.232\right)$.

However, the characteristics of the model in the regression corresponding to the contrarian profits indicate that the explanatory power of the model is too weak given that the $R^{2}$ does not exceed $2.29 \%$ for the period 1991-2013 and 4.74\% for the sub-period 2000-2013. In addition, the model is not globally significant as the probability of the Fisher Statistic is generally higher than the conventional levels of significance especially for the sub-period 2000-2013. The low explanatory power probably indicates the need to include other explanatory factors to the CAPM. Next, we estimate the three-factor model of Fama and French $(1993,1996)$.

Table 2. Contrarian profits adjusted for market risk: January 1991-December 2013

\begin{tabular}{|c|c|c|c|c|c|}
\hline \multicolumn{6}{|c|}{$R_{p, t}-R_{f, t}=\alpha+\beta\left(R_{m, t}-R_{f, t}\right)+\varepsilon_{t}$} \\
\hline Portfolios & $\alpha$ & $\beta$ & $D W$ & $\operatorname{Pr}(F)$ & $R^{2}$ \\
\hline \multicolumn{6}{|c|}{24 month-formation period: $[t-24, t-1]$} \\
\hline Loser & $\begin{array}{l}-0.0008 \\
(-0.366)\end{array}$ & $\begin{array}{l}0.5301 * * * \\
(12.02)\end{array}$ & 1.97 & $0.00 \%$ & $34.52 \%$ \\
\hline Winner & $\begin{array}{l}-0.0050 * * \\
(-2.170)\end{array}$ & $\begin{array}{l}0.7010^{* * * *} \\
(15.73)\end{array}$ & 1.98 & $0.00 \%$ & $47.46 \%$ \\
\hline Loser - Winner & $\begin{array}{l}0.0041 \\
(1.195) \\
\end{array}$ & $\begin{array}{l}-0.1708^{* *} \\
(-2.534) \\
\end{array}$ & 1.95 & $1.18 \%$ & $02.29 \%$ \\
\hline \multicolumn{6}{|c|}{36 month-formation period: $[t-36, t-1]$} \\
\hline Loser & $\begin{array}{l}0.0020 \\
(0.949)\end{array}$ & $\begin{array}{l}0.5823^{* * *} * \\
(14.08)\end{array}$ & 1.82 & $0.00 \%$ & $42.01 \%$ \\
\hline Winner & $\begin{array}{l}-0.0051 * * \\
(-2.306)\end{array}$ & $\begin{array}{l}0.6292 * * * \\
(14.52)\end{array}$ & 1.84 & $0.00 \%$ & $43.49 \%$ \\
\hline Loser-Winner & $\begin{array}{l}0.0072 * * \\
(2.284) \\
\end{array}$ & $\begin{array}{l}-0.0468 \\
(-0.768) \\
\end{array}$ & 1.87 & $44.26 \%$ & $00.21 \%$ \\
\hline \multicolumn{6}{|c|}{48 month-formation period mois : $[t-48, t-1]$} \\
\hline Loser & $\begin{array}{l}0.0028 \\
(1.331)\end{array}$ & $\begin{array}{l}0.5491 \text { *** } \\
(13.16)\end{array}$ & 1.80 & $0.00 \%$ & $38.75 \%$ \\
\hline Winner & $\begin{array}{l}-0.0066 * * * \\
(-2.907)\end{array}$ & $\begin{array}{l}0.7035^{* * *} \\
(15.96)\end{array}$ & 1.54 & $0.00 \%$ & $48.18 \%$ \\
\hline Loser-Winner & $\begin{array}{l}0.0095 * * * \\
(2.879) \\
\end{array}$ & $\begin{array}{l}-0.1543^{* *} \\
(-2.419) \\
\end{array}$ & 1.61 & $01.61 \%$ & $02.09 \%$ \\
\hline \multicolumn{6}{|c|}{24 month-formation period: $[t-36, t-13]$} \\
\hline Loser & $\begin{array}{l}0.0012 \\
(0.514)\end{array}$ & $\begin{array}{l}0.5471 * * * \\
(12.01)\end{array}$ & 1.96 & $0.00 \%$ & $34.51 \%$ \\
\hline Winner & $\begin{array}{l}-0.0045^{* *} \\
(-2.149)\end{array}$ & $\begin{array}{l}0.6122^{* * *} \\
(15.16)\end{array}$ & 1.80 & $0.00 \%$ & $45.64 \%$ \\
\hline Loser -Winner & $\begin{array}{l}0.0057^{*} \\
(1.908)\end{array}$ & $\begin{array}{l}-0.0651 \\
(-1.128)\end{array}$ & 1.87 & $26.01 \%$ & $00.46 \%$ \\
\hline
\end{tabular}




\begin{tabular}{|c|c|c|c|c|c|}
\hline \multicolumn{6}{|c|}{36 month-formation period: $[t-48, t-13]$} \\
\hline Loser & $\begin{array}{l}-0.0002 \\
(-0.137)\end{array}$ & $\begin{array}{l}0.5713 * * * \\
(14.11)\end{array}$ & 2.12 & $0.00 \%$ & $42.08 \%$ \\
\hline Winner & $\begin{array}{l}-0.0058^{* *} \\
(-2.570)\end{array}$ & $\begin{array}{l}0.5954 * * * \\
(13.635)\end{array}$ & 1.85 & $0.00 \%$ & $40.42 \%$ \\
\hline Loser -Winner & $\begin{array}{l}0.0055^{*} \\
(1.838)\end{array}$ & $\begin{array}{l}-0.0240 \\
(-0.415)\end{array}$ & 2.04 & $67.83 \%$ & $00.06 \%$ \\
\hline \multicolumn{6}{|c|}{48 month-formation period: $[t-60, t-13]$} \\
\hline Loser & $\begin{array}{l}0.0009 \\
(0.390)\end{array}$ & $\begin{array}{l}0.5440 * * * \\
(11.94)\end{array}$ & 2.18 & $0.00 \%$ & $34.22 \%$ \\
\hline Winner & $\begin{array}{l}-0.0036^{*} \\
(-1.802)\end{array}$ & $\begin{array}{l}0.6665^{* * * *} \\
(16.87)\end{array}$ & 2.10 & $0.00 \%$ & $50.95 \%$ \\
\hline Loser -Winner & $\begin{array}{l}0.0046 \\
(1.522)\end{array}$ & $\begin{array}{l}-0.1225 * * \\
(-2.095)\end{array}$ & 2.21 & $03.70 \%$ & $01.57 \%$ \\
\hline
\end{tabular}

Note. $R_{P}$ is the return of the loser, winner or arbitrage portfolio. $R_{m}$ is the market return calculated as the value-weighted return of all the stocks composing the sample at time $t$. $R_{f}$ is the risk free rate proxied by the money market rate. The winner (loser) portfolio is the tercile consisting of the stocks that have had the highest (the lowest) returns on a formation period $[t-x, t-y]$. The arbitrage portfolio consists of a long position on the loser and a short position on the winner (Loser minus winner). Numbers in parentheses are $t$ statistics. ***, ** and * indicate significance at $1 \%, 5 \%$ and $10 \%$ levels.

\subsubsection{Adjusting Contrarian Profits for the Three Factors of Fama and French $(1993,1996)$}

Table 3 presents the estimation results after adjusting the loser, the winner and the loser minus winner portfolios' returns for the market risk, the size and the book-to-market equity factors. Note, first, that adding the two factors has improved the explanatory power of the model especially for the arbitrage portfolio. For example, for the formation period [t-24, t-1], $R^{2}$ has increased from $2.29 \%$ for the CAPM to $9.28 \%$ for the three-factor model. In addition, the global significance of the model has considerably improved given that the probability of the Fischer statistic is less than 5\% and, in the vast majority of cases, equal to zero. Certainly, the winner and the loser portfolios demonstrate sensitivity to the market as in the case of the CAPM since beta is still significant, but the loser is no longer less risky than the winner. The contrarian profits, given by the estimated intercept, are not significantly different from zero except for the formation period [t-48, t-1]. They remain not significant after allowing for a 12-month implementation delay.

Table 3. Contrarian profits adjusted for the three risk factors: 1991-2013

\begin{tabular}{|c|c|c|c|c|c|c|c|}
\hline \multicolumn{8}{|c|}{$R_{p, t}-R_{f, t}=\alpha+\beta\left(R_{m, t}-R_{f, t}\right)+s R_{S M B, t}+h R_{H M L, t}+\varepsilon_{t}$} \\
\hline Portfolios & $\alpha$ & $\beta$ & $s$ & $h$ & $D W$ & $\operatorname{Pr}(F)$ & $R^{2}$ \\
\hline \multicolumn{8}{|c|}{24 month-formation period: $[t-24, t-1]$} \\
\hline Loser & $\begin{array}{l}-0.0031 \\
(-1.419)\end{array}$ & $\begin{array}{l}0.6588 * * * \\
(13.83)\end{array}$ & $\begin{array}{l}0.2890^{* * *} \\
(5.665)\end{array}$ & $\begin{array}{l}0.0746 \\
(1.545)\end{array}$ & 2.08 & $00.00 \%$ & $48.11 \%$ \\
\hline Winner & $\begin{array}{l}-0.0064 * * * \\
(-2.776)\end{array}$ & $\begin{array}{l}0.7858^{* * * *} \\
(15.81)\end{array}$ & $\begin{array}{l}0.1916^{* * *} \\
(3.599)\end{array}$ & $\begin{array}{l}0.0352 \\
(0.698)\end{array}$ & 1.97 & $00.00 \%$ & $51.90 \%$ \\
\hline$L-W$ & $\begin{array}{l}0.0032 \\
(0.917)\end{array}$ & $\begin{array}{l}-0.1269^{*} \\
(-1.654)\end{array}$ & $\begin{array}{l}0.0973 \\
(1.184)\end{array}$ & $\begin{array}{l}0.0394 \\
(0.506)\end{array}$ & 1.96 & $05.08 \%$ & $9.28 \%$ \\
\hline \multicolumn{8}{|c|}{36 month-formation period: $[t-36 . t-1]$} \\
\hline Loser & $\begin{array}{l}-0.0010 \\
(-0.532)\end{array}$ & $\begin{array}{l}0.7171 * * * \\
(16.47)\end{array}$ & $\begin{array}{l}0.2942 * * * \\
(6.311)\end{array}$ & $\begin{array}{l}0.1863 * * * \\
(4.221)\end{array}$ & 1.94 & $00.00 \%$ & $48.11 \%$ \\
\hline Winner & $\begin{array}{l}-0.0061 * * * \\
(-2.689)\end{array}$ & $\begin{array}{l}0.6918 * * * \\
(14.18)\end{array}$ & $\begin{array}{l}0.1426 * * * \\
(2.730)\end{array}$ & $\begin{array}{l}0.0094 \\
(0.191)\end{array}$ & 1.84 & $00.00 \%$ & $51.90 \%$ \\
\hline $\mathrm{L}-\mathrm{W}$ & $\begin{array}{l}0.0050 \\
(1.577) \\
\end{array}$ & $\begin{array}{l}0.0252 \\
(0.369) \\
\end{array}$ & $\begin{array}{l}0.1515^{* *} \\
(2.066) \\
\end{array}$ & $\begin{array}{l}0.1769 * * \\
(2.546) \\
\end{array}$ & 1.89 & $02.59 \%$ & $9.28 \%$ \\
\hline \multicolumn{8}{|c|}{48 month-formation period: $[t-48 . t-1]$} \\
\hline Loser & $\begin{array}{l}-0.0004 \\
(-0.207)\end{array}$ & $\begin{array}{l}0.6781 * * * \\
(15.50)\end{array}$ & $\begin{array}{l}0.2777 * * * \\
(5.927)\end{array}$ & $\begin{array}{l}0.2286^{* * * *} \\
(5.151)\end{array}$ & 1.83 & $00.00 \%$ & $48.11 \%$ \\
\hline Winner & $\begin{array}{l}-0.0074 * * * \\
(-3.164)\end{array}$ & $\begin{array}{l}0.7350^{* * * *} \\
(14.66)\end{array}$ & $\begin{array}{l}0.0681 \\
(1.269)\end{array}$ & $\begin{array}{l}0.0519 \\
(1.020)\end{array}$ & 1.54 & $00.00 \%$ & $51.90 \%$ \\
\hline $\mathrm{L}-\mathrm{W}$ & $\begin{array}{l}0.0070^{* *} \\
(2.093)\end{array}$ & $\begin{array}{l}-0.0568 \\
(-0.796) \\
\end{array}$ & $\begin{array}{l}0.2096^{* * *} * \\
(2.739)\end{array}$ & $\begin{array}{l}0.1767 * * \\
(2.438) \\
\end{array}$ & 1.59 & $00.08 \%$ & $9.28 \%$ \\
\hline
\end{tabular}




\begin{tabular}{|c|c|c|c|c|c|c|c|}
\hline \multicolumn{8}{|c|}{24 month-formation period : [t-36.t-13] } \\
\hline Loser & $\begin{array}{l}-0.0022 \\
(-0.995)\end{array}$ & $\begin{array}{l}0.6660^{* * * *} \\
(13.84)\end{array}$ & $\begin{array}{l}0.2511 * * * \\
(4.871)\end{array}$ & $\begin{array}{l}0.2755^{* * *} \\
(5.642)\end{array}$ & 2.07 & $00.00 \%$ & $48.11 \%$ \\
\hline Winner & $\begin{array}{l}-0.0048 * * \\
(-2.285)\end{array}$ & $\begin{array}{l}0.6569 * * * \\
(14.42)\end{array}$ & $\begin{array}{l}0.1053 * * \\
(2.161)\end{array}$ & $\begin{array}{l}-0.0425 \\
(-0.921)\end{array}$ & 1.82 & $00.00 \%$ & $51.90 \%$ \\
\hline $\mathrm{L}-\mathrm{W}$ & $\begin{array}{l}0.0026 \\
(0.891) \\
\end{array}$ & $\begin{array}{l}0.0091 \\
(0.145) \\
\end{array}$ & $\begin{array}{l}0.1457 * * \\
(2.159) \\
\end{array}$ & $\begin{array}{l}0.3180 * * * \\
(4.976)\end{array}$ & 1.86 & $00.00 \%$ & $9.28 \%$ \\
\hline \multicolumn{8}{|c|}{36 month-formation period: $[t-48 . t-13]$} \\
\hline Loser & $\begin{array}{l}-0.0033^{*} \\
(-1.660)\end{array}$ & $\begin{array}{l}0.6833 * * * * \\
(15.93)\end{array}$ & $\begin{array}{l}0.2391 \text { *** } \\
(5.205)\end{array}$ & $\begin{array}{l}0.2259 * * * \\
(5.192)\end{array}$ & 2.16 & $00.00 \%$ & $48.11 \%$ \\
\hline Winner & $\begin{array}{l}-0.0066 * * * \\
(-2.838)\end{array}$ & $\begin{array}{l}0.6246^{* * * *} \\
(12.57)\end{array}$ & $\begin{array}{l}0.0625 \\
(1.174)\end{array}$ & $\begin{array}{l}0.0567 \\
(1.126)\end{array}$ & 1.87 & $00.00 \%$ & $51.90 \%$ \\
\hline $\mathrm{L}-\mathrm{W}$ & $\begin{array}{l}0.0032 \\
(1.073)\end{array}$ & $\begin{array}{l}0.0587 \\
(0.904)\end{array}$ & $\begin{array}{l}0.1766 * * \\
(2.538)\end{array}$ & $\begin{array}{l}0.1692 * * \\
(2.567)\end{array}$ & 2.01 & $01.41 \%$ & $9.28 \%$ \\
\hline \multicolumn{8}{|c|}{48 month-formation period: $[t-60 . t-13]$} \\
\hline Loser & $\begin{array}{l}-0.0032 \\
(-1.519)\end{array}$ & $\begin{array}{l}0.7056^{* * * *} \\
(15.27)\end{array}$ & $\begin{array}{l}0.3471 * * * * \\
(7.013)\end{array}$ & $\begin{array}{l}0.2971 * * * \\
(6.337)\end{array}$ & 2.30 & $00.00 \%$ & $48.11 \%$ \\
\hline Winner & $\begin{array}{l}-0.0047 * * \\
(-2.245)\end{array}$ & $\begin{array}{l}0.6913 * * * * \\
(15.47)\end{array}$ & $\begin{array}{l}0.0487 \\
(1.019)\end{array}$ & $\begin{array}{l}0.1025^{* *} \\
(2.262)\end{array}$ & 2.10 & $00.00 \%$ & $51.90 \%$ \\
\hline $\mathrm{L}-\mathrm{W}$ & $\begin{array}{l}0.0014 \\
(0.470)\end{array}$ & $\begin{array}{l}0.0143 \\
(0.224) \\
\end{array}$ & $\begin{array}{l}0.2983 * * * \\
(4.346)\end{array}$ & $\begin{array}{l}0.1946 * * * \\
(2.992)\end{array}$ & 2.24 & $00.00 \%$ & $9.28 \%$ \\
\hline
\end{tabular}

Note. $R_{S M B, t}$ is the difference, in month $t$, between the return on the portfolio of small stocks and the return on portfolio of large stocks (Small Minus Big). $R_{H M L, t}$ is difference, in month $t$, between the return on portfolio of high Book to Market stocks and the return on portfolio of low Book to Market stocks (High Minus Low). $R_{S M B}$ and $R_{H M L}$ are calculated as in Fama and French (1993, 1996). Numbers in parentheses are $t$ statistics. $* * *, * *$ and $*$ indicate significance at $1 \%, 5 \%$ and $10 \%$ levels. DW is the Durbin-Watson statistic. $\operatorname{Pr}(F)$ is the probability corresponding to the Fisher statistic. For the definition of the other variables see notes of the preceding table.

Furthermore, the size and the book-to-market effects generally seem to contribute, with the market risk, to the explanation of the contrarian profits. The coefficient corresponding to the size factor in the loser portfolio regressions is significantly positive and always greater than the coefficient in the winner portfolio regressions. For example, for the formation period $[t-36, t-1] s_{L}=0.2942(t=6.311)$ and $s_{W}=0.1426(t=2.730)$. This implies that the loser is more sensitive to the size factor and its performance relative to the winner (found above with the CAPM) is due to the fact that the firms composing the loser portfolio are small relative to those composing the winner portfolio.

Moreover, the risk related to the book-to-market equity seems to explain, in some cases, the loser and the arbitrage portfolios abnormal returns. Note, also, that the loser portfolio is more sensitive to this factor than the winner portfolio. For example, for the rank period $[t-36, t-1], h_{L}=0.1863(t=4.221)$ and $h_{W}=0.0094(t=$ 0.191). This implies, again, that the outperformance of the loser relative to the winner is explained by the Book to Market effect; and the loser portfolio seems to be composed of firms with high Book to Market ratio. This is consistent with the work of Nagel (2001) who found that the reversal effect on the U.S. and U.K. markets is due to the book-to- market effect.

These results are robust for the sub-period 2000-2013 (available on request) and corroborate those of Fama and French (1996). Next, we examine the impact of the two psychological factors on the portfolios' returns.

\subsubsection{Do Behavioral Factors Explain Contrarian Profits?}

As mentioned above, before extracting the series reflecting the investor overconfidence a preliminary test should be performed to ensure that overconfidence exists in the Tunisian stock market. The existence of such a bias is justified by the existence of a one-direction causality from past market returns to the trading volume. The VAR model that serves to study this relationship is given by the model (8).

To study the stationarity of the two variables $R_{m}$ and $V$, we run an ADF test. The results are shown in Table 4 . After applying the sequential procedure to select the appropriate ADF model, we can conclude that the two series are stationary in level. 
Table 4. Unit root test for $R_{m}$ and $V$

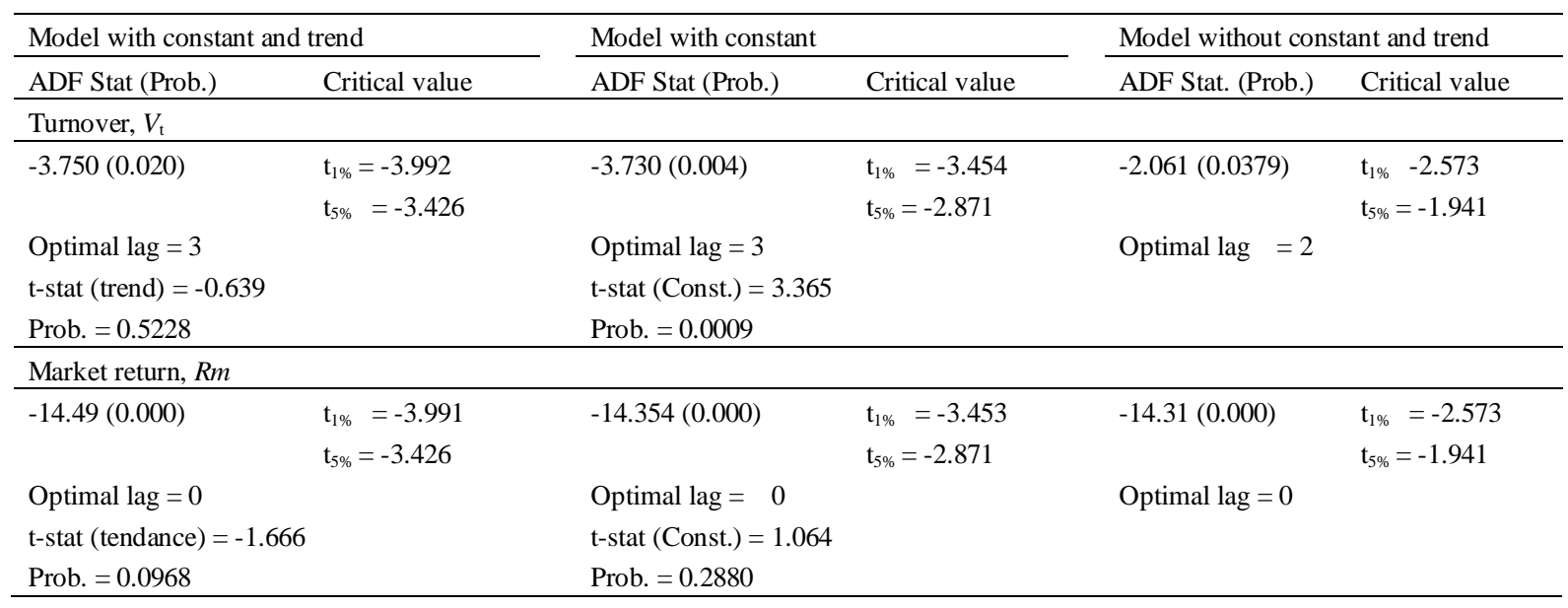

Note. The null hypothesis is that the series has a unit root. The table displays the Augmented Dickey-Fuller test, the associated probabilities (in parentheses) and the critical values at the $1 \%$ and 5\% levels for each of the three models of Dickey and Fuller (1981). The optimal lag is selected based on Schwarz (1978) criterion. A lag equal to 0 means that the considered model is one of the three models of Dicey and Fuller (1969). This is the case if no lag is significant in the ADF test.

Results from the Granger causality test between the turnover and the market returns after performing the preliminary tests (stationarity of the variables and selecting the optimal lag of the model) are reported in Table 5. The probability of $\chi_{1}^{2}$ statistic corresponding to the lagged coefficients of $R_{m}$ in the first equation is equal to $5.52 \%$, less than the $10 \%$ level indicating that we can reject the null hypothesis « $\theta_{l j}=0$ for $j=1,2$ or 3 » or similarly the null hypothesis « $R_{\mathrm{m}}$ does not Granger cause $V »$. We deduce that the market return Granger causes the trading volume. However, we do not reject the null hypothesis " $V$ does not Granger cause $R_{m}$ ". This implies that there is a one-direction causal relationship from $R_{m}$ to $V$.

In addition, the sum of the lagged coefficients corresponding to $R_{m}$ in the first equation is positive $\left(\theta_{11}+\theta_{12}+\theta_{13}=0.0188\right)$ and significantly different from zero at the $10 \%$ level $\left[\operatorname{Prob}\left(\chi_{2}^{2}\right)=5.47 \%\right]$. This indicates that there is a positive cumulative effect of the past returns on the current trading volume which means that past market gains help forecast an increase in trading volume. The Tunisian investors seem, therefore, to attribute market gains to their own performance when selecting stocks and, hence, they excessively trade stocks in the subsequent period, which indicates that they are victims of the self-attribution and the overconfidence biases.

This finding is consistent with the empirical work of, among others, Chuang and Lee (2006), Darrat et al. (2007) and Statman (2006) in the US market and Griffin, Nardari and Stulz (2007) in 46 high-income and developing markets. Besides, it seems to partially support the model of Daniel et al. (1998) developed to reconcile the investors' overreaction and underreaction based on the overconfidence bias. Furthermore, it is in line with the psychology literature showing that people exhibit a self-attribution bias. 
Table 5. Causality between trading volume and market return

\begin{tabular}{|c|c|c|c|c|}
\hline \multicolumn{5}{|c|}{$\begin{array}{l}V_{t}=\alpha_{1}+\sum_{j=1}^{3} \beta_{1 j} V_{t-j}+\sum_{j=1}^{3} \theta_{1 j} R m_{t-j}+\varepsilon_{1 t} \\
R m_{t}=\alpha_{2}+\sum_{j=1}^{3} \beta_{2 j} V_{t-j}+\sum_{j=1}^{3} \theta_{2 j} R m_{t-j}+\varepsilon_{2 t}\end{array}$} \\
\hline \multirow{2}{*}{$\begin{array}{l}\text { Dependent variable } \\
\text { Independent variable }\end{array}$} & \multicolumn{2}{|l|}{$V_{t}$} & \multicolumn{2}{|l|}{$R m_{t}$} \\
\hline & $V_{t-j}$ & $R m_{t-j}$ & $V_{t-j}$ & $R m_{t-j}$ \\
\hline \multirow{2}{*}{$\chi_{1}^{2} \quad$ [prob.] } & 127.7 & 7.592 & 0.801 & 6.226 \\
\hline & {$[0.000]$} & {$[0.055]$} & [0.849] & {$[0.101]$} \\
\hline Sum of lagged coefficients & 0.698 & 0.018 & 0.021 & 0.236 \\
\hline \multirow[t]{2}{*}{$\chi_{2}^{2} \quad[$ prob.] } & 127.2 & 3.691 & 0.001 & 5.585 \\
\hline & {$[0.000]$} & {$[0.054]$} & {$[0.972]$} & {$[0.018]$} \\
\hline$R^{2}$ & 0.3719 & & 0.0254 & \\
\hline
\end{tabular}

Notes. $V_{t}$ is the trading volume measured by the turnover. $R m_{t}$ is the market return calculated as the value-weighted return of all the stocks composing the sample at time $t$. The optimal lag, determined based on the Akaike (1974) criterion, is $p=3$. The $\chi_{1}^{2}$ statistic is a joint test of the null hypothesis that the lagged coefficients are equal to zero. The $\chi_{2}^{2}$ test statistic is used to test the null hypothesis that the sum of the estimated lagged coefficients is equal to zero. Numbers between parentheses are the probabilities corresponding to these statistics The above analysis suggests that part of the trading volume is explained by these biases. It is therefore possible to extract the series of the variable reflecting overconfidence, from the volume decomposition equation (7). We proceed next to the estimation of our model.

The estimation results of the model (3) for the period 1991-2013 are displayed in Table 6. The ARMS index reflecting the investor sentiment (investor optimism or pessimism) does not contribute in any way to the explanation of the three portfolios' returns as its associated coefficient is not significantly different from zero. However, the overconfidence (CONF) appears to explain the winner and the arbitrage portfolios' returns except for the rank period $[t-24, t-1]$. For example, for the formation period $[t-36, t-1]$, the excess return of the winner portfolio is $-0.5 \%$ ( $t$ student $=-2.40$ ). Investors, therefore, tend to react with overconfidence to the past gains by mistakenly attributing them to their ability to select stocks. Victims of this bias, they trade aggressively, thereby, causing a price deviation from the fundamental value. The subsequent reversal of the winner portfolio performance reflects a correction of this overreaction and a price mean reversion to the fundamental value. Note that the effect of the investor confidence is asymmetric since it explains only the reversal of the winner portfolio but not the loser one. The confidence asymmetric effect implies that the investors tend generally to exhibit overconfidence to past market gains but not underconfidence to past market losses. Note also that the coefficient corresponding to the confidence variable is large compared to the other coefficients indicating that the effect of this bias is important compared to the market risk, the size and the book-to-market effects.

As in the previous model, once adjusted to the three factors of Fama and French $(1993,1996)$ and the two "behavioral" factors, the abnormal contrarian profits disappear. Similar results are obtained for the sub-period 2000-2013 (available on request).

In sum, the abnormal returns generated by the contrarian strategy on the Tunisian stock market are explained by the market risk (beta), the size effect and the Book-to-market effect and once they are adjusted for these three risk factors, they disappear although the reversal of the winner portfolio remains significant. However, only the factor reflecting overconfidence among the two added behavioral factors appears to play a role in explaining these returns. We think that it would be appropriate to construct a "psychological risk premium" as an extension to the three-factor model of Fama and French $(1993,1996)$. 
Table 6. Explanation of the contrarian profits by rational and behavioral factors

\begin{tabular}{|c|c|c|c|c|c|c|c|c|c|}
\hline \multicolumn{10}{|c|}{$R_{p, t}-R_{f, t}=\alpha+\beta\left(R_{m, t}-R_{f, t}\right)+s R_{S M B, t}+h R_{H M L, t}+m A R M S_{t}+f C O N F_{t}+\varepsilon_{t}$} \\
\hline Prtfs. & $\alpha$ & $\beta$ & $s$ & $h$ & $m$ & $f$ & $D W$ & $\operatorname{Pr}(F)$ & $R^{2}$ \\
\hline \multicolumn{10}{|c|}{24 month-formation period: $[t-24, t-1]$} \\
\hline Loser & $\begin{array}{l}-0.003 \\
(-1.48)\end{array}$ & $\begin{array}{l}0.663 * * * \\
(12.7)\end{array}$ & $\begin{array}{l}0.287 * * * \\
(5.50)\end{array}$ & $\begin{array}{l}0.079 \\
(1.59)\end{array}$ & $\begin{array}{l}0.0001 \\
(0.26)\end{array}$ & $\begin{array}{l}0.509 \\
(0.38)\end{array}$ & 2.06 & $0.00 \%$ & $39,13 \%$ \\
\hline Winner & $\begin{array}{l}-0.006 * * * \\
(-2.58)\end{array}$ & $\begin{array}{l}0.760^{* * *} \\
(13.9)\end{array}$ & $\begin{array}{l}0.186^{* * * *} \\
(3.40)\end{array}$ & $\begin{array}{l}0.028 \\
(0.54)\end{array}$ & $\begin{array}{l}-3.4 \mathrm{E}-5 \\
(-0.06)\end{array}$ & $\begin{array}{l}2.168 \\
(1.56)\end{array}$ & 1.91 & $0.00 \%$ & $46,45 \%$ \\
\hline $\mathrm{L}-\mathrm{W}$ & $\begin{array}{l}0.002 \\
(0.74)\end{array}$ & $\begin{array}{l}-0.097 \\
(-1.15)\end{array}$ & $\begin{array}{l}0.101 \\
(1.20)\end{array}$ & $\begin{array}{l}0.051 \\
(0.63)\end{array}$ & $\begin{array}{l}0.0001 \\
(0.20)\end{array}$ & $\begin{array}{l}-1.658 \\
(-0.77)\end{array}$ & 1.90 & $24,83 \%$ & $2,47 \%$ \\
\hline \multicolumn{10}{|c|}{36 month-formation period : $[t-36, t-1]$} \\
\hline Loser & $\begin{array}{l}-0.001 \\
(-0.49)\end{array}$ & $\begin{array}{l}0.713 * * * \\
(14.9)\end{array}$ & $\begin{array}{l}0.290 * * * \\
(6.06)\end{array}$ & $\begin{array}{l}0.187 * * * \\
(4.12)\end{array}$ & $\begin{array}{l}-6.5 \mathrm{E}-5 \\
(-0.13)\end{array}$ & $\begin{array}{l}-0.425 \\
(-0.34)\end{array}$ & 1.93 & $0.00 \%$ & $47,10 \%$ \\
\hline Winner & $\begin{array}{l}-0.005^{* *} \\
(-2.40)\end{array}$ & $\begin{array}{l}0.701 * * * \\
(13.3)\end{array}$ & $\begin{array}{l}0.149 * * * \\
(2.85)\end{array}$ & $\begin{array}{l}0.022 \\
(0.45)\end{array}$ & $\begin{array}{l}-7.8 \mathrm{E}-5 \\
(-0.14)\end{array}$ & $\begin{array}{l}2.955^{* *} \\
(2.21)\end{array}$ & 1.92 & $0.00 \%$ & $45,44 \%$ \\
\hline $\mathrm{L}-\mathrm{W}$ & $\begin{array}{l}0.004 \\
(1.37) \\
\end{array}$ & $\begin{array}{l}0.012 \\
(0.16) \\
\end{array}$ & $\begin{array}{l}0.140^{*} \\
(1.88)\end{array}$ & $\begin{array}{l}0.164 * * \\
(2.32)\end{array}$ & $\begin{array}{l}1.3 \mathrm{E}-5 \\
(0.01) \\
\end{array}$ & $\begin{array}{l}-3.381 * \\
(-1.78)\end{array}$ & 1.94 & $6,03 \%$ & $3,91 \%$ \\
\hline \multicolumn{10}{|c|}{48 month-formation period : $[t-48, t-1]$} \\
\hline Loser & $\begin{array}{l}-0.0001 \\
(-0.07)\end{array}$ & $\begin{array}{l}0.678^{* * *} \\
(14.1)\end{array}$ & $\begin{array}{l}0.272 * * * \\
(5.65)\end{array}$ & $\begin{array}{l}0.231 * * * \\
(5.05)\end{array}$ & $\begin{array}{l}6.9 \mathrm{E}-5 \\
(0.14)\end{array}$ & $\begin{array}{l}-0.881 \\
(-0.71)\end{array}$ & 1.82 & $0.00 \%$ & $44,72 \%$ \\
\hline Winner & $\begin{array}{l}-0.007 * * * \\
(-3.06)\end{array}$ & $\begin{array}{l}0.746^{* * *} \\
(14.1)\end{array}$ & $\begin{array}{l}0.077 \\
(1.46)\end{array}$ & $\begin{array}{l}0.064 \\
(1.27)\end{array}$ & $\begin{array}{l}-3.5 \mathrm{E}-6 \\
(-0.00)\end{array}$ & $\begin{array}{l}4.885^{* * * *} \\
(3.64)\end{array}$ & 1.66 & $0.00 \%$ & $51,22 \%$ \\
\hline $\mathrm{L}-\mathrm{W}$ & $\begin{array}{l}0.007 * * \\
(2.05)\end{array}$ & $\begin{array}{l}-0.067 \\
(-0.88)\end{array}$ & $\begin{array}{l}0.195 * * \\
(2.54)\end{array}$ & $\begin{array}{l}0.167 * * \\
(2.29)\end{array}$ & $\begin{array}{l}\text { 7. 3E-5 } \\
(0.09)\end{array}$ & $\begin{array}{l}-5.76 * * * \\
(-2.95) \\
\end{array}$ & 1.66 & $0.03 \%$ & $8,52 \%$ \\
\hline \multicolumn{10}{|c|}{24 month-formation period: $[t-36, t-13]$} \\
\hline Loser & $\begin{array}{l}-0.002 \\
(-1.14)\end{array}$ & $\begin{array}{l}0.612^{* * * *} \\
(11.8)\end{array}$ & $\begin{array}{l}0.227 * * * \\
(4.41)\end{array}$ & $\begin{array}{l}0.250 * * * \\
(5.10)\end{array}$ & $\begin{array}{l}-2.9 \mathrm{E}-5 \\
(-0.05)\end{array}$ & $\begin{array}{l}0.110 \\
(-0.08)\end{array}$ & 2.09 & $0.00 \%$ & $37,75 \%$ \\
\hline Winner & $\begin{array}{l}-0.005^{* *} \\
(-2.30)\end{array}$ & $\begin{array}{l}0.614 * * * \\
(12.5)\end{array}$ & $\begin{array}{l}0.089 * \\
(1.82)\end{array}$ & $\begin{array}{l}-0.056 \\
(-1.20)\end{array}$ & $\begin{array}{l}9.7 \mathrm{E}-5 \\
(0.19)\end{array}$ & $\begin{array}{l}4.077 * * * \\
(3.27)\end{array}$ & 1.84 & $0.00 \%$ & $45,23 \%$ \\
\hline $\mathrm{L}-\mathrm{W}$ & $\begin{array}{l}0.002 \\
(0.80) \\
\end{array}$ & $\begin{array}{l}-0.002 \\
(-0.03) \\
\end{array}$ & $\begin{array}{l}0.138 * * \\
(2.05)\end{array}$ & $\begin{array}{l}0.307^{* * * *} \\
(4.78)\end{array}$ & $\begin{array}{l}-0.0001 \\
(-0.18) \\
\end{array}$ & $\begin{array}{l}-4.188 * * \\
(-2.44)\end{array}$ & 1.89 & $0.00 \%$ & $10,35 \%$ \\
\hline \multicolumn{10}{|c|}{36 month-formation period: $[t-48, t-13]$} \\
\hline Loser & $\begin{array}{l}0.003 \\
(-1.56)\end{array}$ & $\begin{array}{l}0.669 * * * \\
(14.1)\end{array}$ & $\begin{array}{l}0.226^{* * *} \\
(4.78)\end{array}$ & $\begin{array}{l}0.217 * * * \\
(4.83)\end{array}$ & $\begin{array}{l}0.0001 \\
(0.24)\end{array}$ & $\begin{array}{l}-0.048 \\
(-0.04)\end{array}$ & 2.16 & $0.00 \%$ & $45,58 \%$ \\
\hline Winner & $\begin{array}{l}-0.006^{* * *} \\
(-2.61)\end{array}$ & $\begin{array}{l}0.597 * * * \\
(11.0)\end{array}$ & $\begin{array}{l}0.041 \\
(0.75)\end{array}$ & $\begin{array}{l}0.039 \\
(0.76)\end{array}$ & $\begin{array}{l}-0.0002 \\
(-0.46)\end{array}$ & $\begin{array}{l}3.062 * * \\
(2.21)\end{array}$ & 1.89 & $0.00 \%$ & $38,99 \%$ \\
\hline $\mathrm{L}-\mathrm{W}$ & $\begin{array}{l}0.003 \\
(0.95) \\
\end{array}$ & $\begin{array}{l}0.071 \\
(1.00) \\
\end{array}$ & $\begin{array}{l}0.185^{* * *} \\
(2.58)\end{array}$ & $\begin{array}{l}0.177 * * * \\
(2.60)\end{array}$ & $\begin{array}{l}0.0003 \\
(0.51) \\
\end{array}$ & $\begin{array}{l}-3.110^{*} \\
(-1.70) \\
\end{array}$ & 2.03 & $2,57 \%$ & $4,69 \%$ \\
\hline \multicolumn{10}{|c|}{48 month-formation period: $[t-60, t-13]$} \\
\hline Loser & $\begin{array}{l}-0.003 \\
(-1.42)\end{array}$ & $\begin{array}{l}0.664 * * * \\
(13.2)\end{array}$ & $\begin{array}{l}0.328 * * * \\
(6.53)\end{array}$ & $\begin{array}{l}0.278^{* * *} \\
(5.80)\end{array}$ & $\begin{array}{l}0.0001 \\
(0.20)\end{array}$ & $\begin{array}{l}-1.452 \\
(-1.13)\end{array}$ & 2.28 & $0.00 \%$ & $41,73 \%$ \\
\hline Winner & $\begin{array}{l}-0.004 * * \\
(-2.08)\end{array}$ & $\begin{array}{l}0.660 * * * \\
(13.4)\end{array}$ & $\begin{array}{l}0.033 \\
(0.67)\end{array}$ & $\begin{array}{l}0.087 * \\
(1.85)\end{array}$ & $\begin{array}{l}-8.7 \mathrm{E}-5 \\
(-0.17)\end{array}$ & $\begin{array}{l}1.573 \\
(1.25)\end{array}$ & 2.09 & $0.00 \%$ & $47,81 \%$ \\
\hline $\mathrm{L}-\mathrm{W}$ & $\begin{array}{l}0.001 \\
(0.44)\end{array}$ & $\begin{array}{l}0.003 \\
(0.04)\end{array}$ & $\begin{array}{l}0.295^{* * *} * \\
(4.18)\end{array}$ & $\begin{array}{l}0.190 * * * \\
(2.84)\end{array}$ & $\begin{array}{l}0.0001 \\
(0.27)\end{array}$ & $\begin{array}{l}-3.025^{*} \\
(-1.68) \\
\end{array}$ & 2.27 & $0.00 \%$ & $9,96 \%$ \\
\hline
\end{tabular}

Notes. ARMS is used as a sentiment indicator that measures the investor excessive optimism or pessimism. CONF is the variable that measures the investor overconfidence. It is extracted from de trading volume decomposition of Chuang and Lee (2006). For the definition of the other variables see notes of the preceding table. Numbers between parentheses are $t$ statistics. ***,** and * indicate significance at $1 \%, 5 \%$ and $10 \%$ levels. $D W$ is the Durbin-Watson statistic. $\operatorname{Pr}(F)$ is the probability corresponding to the Fisher statistic.

However, it should be noted that our research suffers from some limitations. First, we used only one measure of investor sentiment which is the ARMS index and we found that it does not explain the contrarian profits. Two possible explanations can be advanced to explain this result: the Tunisian investors do not show optimism or pessimism and their investment decisions are independent of this sentiment; or the indicator that we used is insufficient to reflect the investor sentiment. It was not possible to use other investor sentiment proxies in the Tunisian context for two reasons: there are no data on investor sentiment such as the direct measures calculated 
based on surveys; or that some indirect sentiment indicators such as the Put-Call ratio, the Closed-end fund discount and the ratio of short sales to total sales require specific data to be calculated which do not yet exist in the Tunisian context. We also used a single proxy for the variable reflecting the overconfidence bias. We found that overconfidence can contribute to the explanation of the contrarian profits and that its effect does not seem negligible. Other proxies for overconfidence deduced, for example, from a survey conducted on the Tunisian investors could have been used to confirm or disconfirm the contribution of this bias to the explanation of contrarian profits. In this study we did not consider the momentum factor "winner minus loser" added by Carhart (1997) to the three-factor model of Fama and French. Even without this factor, we find that the three-factor model fully explains the contrarian profits in the Tunisian market. This evidence generally supports the three-factor model of Fama and French.

\section{Conclusion}

In this paper, we have tried to test whether the overconfidence and the investor sentiment help explain the contrarian profits in the Tunisian stock market. We used the ARMS index as a proxy for the investor sentiment. The factor reflecting overconfidence is extracted from the decomposition of the trading volume initiated by Chuang and Lee (2006). These two factors are included in the three-factor model of Fama and French (1993, 1996) to adjust returns for market risk, size effect and Book to Market effect. Adding the two behavioral variables to these three factors has allowed us to confront the rational approach with the behavioral approach in an attempt to decide between them.

The results indicate that the market risk, the size effect and the book-to-market effect explain the contrarian profits, which supports the rational approach. This does not seem to reject the behavioral approach since one of the two behavioral factors, the overconfidence, tends to explain the contrarian profits. We can deduce that the overreaction due to the overconfidence bias helps explain the mean reversion phenomenon and the profitability of the contrarian strategy in the Tunisian stock market.

Including behavioral factors in the model of Fama and French $(1993,1996)$ was an attempt to examine whether these factors explain contrarian profits. Since the model of these authors is composed of risk premiums, it would be appropriate to construct a psychological risk premium to account for potential investor irrationality and extend the three factor model.

\section{Acknowledgements}

The author wishes to thank Mohamed Chaker Chafai and two anonymous referees for their helpful comments and suggestions.

\section{References}

Akarim, Y. D., \& Sevim, S. (2013). The impact of mean reversion model on portfolio investment strategies: Empirical evidence from emerging markets. Economic Modelling, 31, 453-459. http://dx.doi.org/10.1016/j.econmod.2012.11.028

Alwathainani, A. M. (2012). Consistent winners and losers. International Review of Economics and Finance, 21(1), 210-220. http://dx.doi.org/10.1016/j.iref.2011.05.009

Baek, S., \& Bilson, J. F. O. (2014). Size and value risk in financial firms. Journal of Banking and Finance, 55, 295-326. http://dx.doi.org/10.1016/j.jbankfin.2014.02.011

Baker, M., \& Wurgler, J. (2006). Investor Sentiment and the Cross-Section of Stock Returns. Journal of Finance, 61(4), 1645-1680. http://dx.doi.org/10.1111/j.1540-6261.2006.00885.x

Bali, T. G., Demirtas, K. O., \& Levy H. (2008). Nonlinear mean reversion in stock prices. Journal of Banking and Finance, 32(5), 762-782. http://dx.doi.org/10.1016/j.jbankfin.2007.05.013

Ball, R., \& Kothari, S. (1989). Nonstationary expected returns: Implications for tests of market efficiency and serial correlation in returns. Journal of Financial Economics, 25(1), 51-74. http://dx.doi.org/10.1016/0304-405X(89)90096-2

Balvers, R., Wu, Y., \& Gilliland, E. (2000). Mean Reversion across National Stock Markets and Parametric

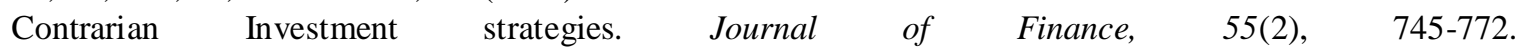
http://dx.doi.org/10.1111/0022-1082.00225

Barberis, N., Shleifer, A., \& Vishny, R. (1998). A model of investor sentiment. Journal of Financial Economics, 49(3), $1-53$.

Bloomfield, R., \& Hales, J. (2002). Predicting the next step of a random walk: Experimental evidence of 
regime-shifting beliefs. Journal of Financial Economics, 65(3), 397-414. http://dx.doi.org/10.1016/S0304-405X(02)00147-2

Brown, G. W., \& Cliff, M. T. (2005). Investor sentiment and asset valuation. Journal of Business, 78(2), 405-436. http://dx.doi.org/10.1086/427633

Campbell, J. Y., \& Shiller, R. J. (1987). Cointegration and tests of present value models. Journal of Political Economy, 95(5), 1062-1088. http://dx.doi.org/10.1086/261502

Carhart, M. M. (1997). On persistence in mutual fund performance. Journal of Finance, 52, 57-82. http://dx.doi.org/10.1111/j.1540-6261.1997.tb03808.x

Chan, K. C. (1988). On the contrarian investment strategy. Journal of Business, 61, 147-163. http://dx.doi.org/10.1086/296425

Chou, P. H., Chung, H., \& Wei, K. C. J. (2007). Sources of contrarian profits in the Japanese stock market. Journal of Empirical Finance, 14, 261-286. http://dx.doi.org/10.1016/j.jempfin.2006.07.003

Chou, R. K., \& Wang, Y. Y. (2011). A test of the different implications of the overconfidence and disposition hypotheses. Journal of Banking and Finance, 35(8), 2037-2046. http://dx.doi.org/10.1016/j.jbankfin.2011.01.018

Chuang, W. I., \& Lee, B. S. (2006). An empirical evaluation of the overconfidence hypothesis. Journal of Banking and Finance, 30(9), 2489-2515. http://dx.doi.org/10.1016/j.jbankfin.2005.08.007

Chuang, W. I., \& Susmel, R. (2011). Who is the more overconfident trader? Individual vs. institutional investors. Journal of Banking and Finance, 35(7), 1626-1644. http://dx.doi.org/10.1016/j.jbankfin.2010.11.013

Daniel, K., Hirshleifer, D., \& Subrahmanyam, A. (1998). Investor psychology and security market under and overreactions. Journal of Finance, 53(6), 1839-1885. http://dx.doi.org/10.1111/0022-1082.00077

Darrat, A. F., Zhong, M., \& Cheng, L. T. W. (2007). Intraday volume and volatility relations with and without public news. Journal of Banking and Finance, 31, 2711-2729. http://dx.doi.org/10.1016/j.jbankfin.2006.11.019

De Bondt, W. F. M., \& Thaler, R. M. (1985). Does the Stock Market Overreact? Journal of Finance, 40(3), 793-805.

De Bondt, W. F. M., \& Thaler, R. M. (1987). Further evidence on investor overreaction and stock market seasonality. Journal of Finance, 42(3), 557-581. http://dx.doi.org/10.1111/j.1540-6261.1985.tb05004.x

Eraker, B. (2008). A Bayesian view of temporary components in asset prices. Journal of Empirical Finance, 15, 503-517. http://dx.doi.org/10.1016/j.jempfin.2007.07.004

Fama, E. F., \& French, K. (1988). Permanent and temporary components of stock prices. Journal of Political Economy, 96(2), 246-273. http://dx.doi.org/10.1086/261535

Fama, E. F., \& French, K. R. (1992). The Cross-Section of Expected Stock Returns. Journal of Finance, 47(2), 427-465. http://dx.doi.org/10.1111/j.1540-6261.1992.tb04398.x

Fama, E. F., \& French, K. R. (1993). Common risk factors in the returns on stocks and bonds. Journal of Financial Economics, 33, 3-56. http://dx.doi.org/10.1016/0304-405X(93)90023-5

Fama, E. F., \& French, K. R. (1996). Multifactor explanations of asset pricing anomalies. Journal of Finance, 5l(1), 55-84. http://dx.doi.org/10.1111/j.1540-6261.1996.tb05202.x

Frieder, L. (2008). Investor and price response to patterns in earnings surprises. Journal of Financial Markets, 11(3), 259-283. http://dx.doi.org/10.1016/j.finmar.2008.02.001

Galariotis, E. C., Holmes, P., \& Ma, X. S. (2007). Contrarian and momentum profitability revisited: Evidence from the London Stock Exchange 1964-2005. Journal of Multinational Financial Management, 17, 432-447. http://dx.doi.org/10.1016/j.mulfin.2007.01.003

Gangopadhyay, P., \& Reinganum, M. R. (1996). Interpreting Mean Reversion in Stock Returns. Quarterly Review of Economics and Finance, 36(3), 377-394. http://dx.doi.org/10.1016/S1062-9769(96)90022-8

Gaunt, C. (2000). Overreaction in the Australian equity market: 1974-1997. Pacific-Basin Finance Journal, 8, 375-398. http://dx.doi.org/10.1016/S0927-538X(00)00017-2

Gervais, S., \& Odean, T. (2001). Learning to Be Overconfident. The Review of Financial Studies, 14(1), 1-27. http://dx.doi.org/10.1093/rfs/14.1.1 
Glaser, M., \& Weber, M. (2007). Overconfidence and trading volume. Geneva Risk and Insurance Review, 32, 1-36. http://dx.doi.org/10.1007/s10713-007-0003-3

Glaser, M., \& Weber, M. (2009). Which past returns affect trading volume? Journal of Financial Markets, 12, 1-31. http://dx.doi.org/10.1016/j.finmar.2008.03.001

Greenwald, A. G. (1980). The totalitarian ego fabrication and revision of personal history. American Psychologist, 35(7), 603-618. http://dx.doi.org/10.1037/0003-066X.35.7.603

Griffin, J. M., Nardari, F., \& Stulz, R. M. (2007). Do investors trade more when stocks have performed well? Evidence from 46 countries. Review of Financial Studies, 20(3), 905-951. http://dx.doi.org/10.1093/rfs/hhl019

Gunaratne, P. S. M., \& Yonesawa, Y. (1997). Return reversals in the Tokyo Stock Exchange: A test of stock market overreaction. Japan and the World Economy, 9(3), 363-384. http://dx.doi.org/10.1016/S0922-1425(96)00256-3

Jegadeesh, N. (1991). Seasonality in Stock Price Mean Reversion: Evidence from the U.S. and the U.K. Journal of Finance, 46, 1427-1444. http://dx.doi.org/10.1111/j.1540-6261.1991.tb04624.x

Kaestner, M. (2006). Anomalous price behaviour following earnings surprises: Does representativeness cause overreaction? Finance: Revue de l'Association Française de Finance, 27(2), 5-31.

Kanas, A. (2005). Nonlinearity in the stock price-dividend relation. Journal of International Money and Finance, 24(4), 583-606. http://dx.doi.org/10.1016/j.jimonfin.2005.03.003

Kapetanios, G., Shin, Y., \& Snell, A. (2006). Testing for cointegration in nonlinear STAR error-correction models. Econometric Theory, 22(2), 279-303. http://dx.doi.org/10.1017/S0266466606060129

Kyle, A. S., \& Wang, F. A. (1997). Speculation duopoly with agreement to disagree: Can overconfidence survive the market test? Journal of Finance, 52, 2073-2090. http://dx.doi.org/10.1111/j.1540-6261.1997.tb02751.x

Lakonishok, J., Shleifer, A., \& Vishny, R. W. (1994). Contrarian Investment, Extrapolation, and Risk. Journal of Finance, 49(5), 1541-1578. http://dx.doi.org/10.1111/j.1540-6261.1994.tb04772.x

Langer, I. J., \& Roth, J. (1975). Heads I Win, Tails It's Chance: The Illusion of Control as a Function of the Sequence of Outcomes in a Purely Chance Task. Journal of Personality and Social Psychology, 32(6), 951-955. http://dx.doi.org/10.1037/0022-3514.32.6.951

Lemmon, M., \& Portniaguina, E. (2006). Consumer confidence and asset prices: Some empirical evidence. Review of Financial Studies, 19, 1499-1529. http://dx.doi.org/10.1093/rfs/hhj038

Lintner, J. (1965). The valuation of risk assets and the selection of risky investments in stock portfolios and capital budgets. Review of Economics and Statistics, 47, 13-37. http://dx.doi.org/10.2307/1924119

Lo, A. W., \& Wang, J. (2000). Trading Volume: definitions, data analysis, and implications of portfolio theory. Review of Financial Studies, 13, 527-300. http://dx.doi.org/10.1093/rfs/13.2.257

McMillan, D. G. (2007). Bubbles in the dividend-price ratio? Evidence from an asymmetric exponential smooth-transition model. Journal of Banking and Finance, 31(3), 787-804. http://dx.doi.org/10.1016/j.jbankfin.2006.02.006

McMillan, D. G. (2009). Revisiting dividend yield dynamics and returns predictability: Evidence from a time-varying ESTR model. The Quarterly Review of Economics and Finance, 49(3), 870-883. http://dx.doi.org/10.1016/j.qref.2008.10.002

Miller, D., \& Ross, M. (1975). Self-serving Biases in Attribution of Causality: Fact or Fiction? Psychological Bulletin, 82, 213-225. http://dx.doi.org/10.1037/h0076486

Mossin, J. (1966). Equilibrium in a capital asset market. Econometrica, 34, 768-783. http://dx.doi.org/10.2307/1910098

Mukherji, S. (2011). Are stock returns still mean-reverting? Review of Financial Economics, 20(1), 22-27. http://dx.doi.org/10.1016/j.rfe.2010.08.001

Mun, G. M., Vasconcellos, R., \& Kish, J. C. (2000). The contrarian/Overreaction hypothesis an analysis of the US and Canadian stock markets. Global Finance Journal, 11, 53-72. http://dx.doi.org/10.1016/S1044-0283(00)00011-9

Nagel, S. (2001). Is It Overreaction? The Performance of Value and Momentum Strategies at Long Horizons. 
SSRN Working paper, EFA 2001 Barcelona Meetings. http://dx.doi.org/10.2139/ssrn.276290

Nagel, S. (2001). Is it overreaction? The performance of value and momentum strategies at the long horizons. Working paper.

Nasseh, A., \& Strauss, J. (2004). Stock prices and the dividend discount model: Did their relation break down in the 1990s? The Quarterly Review of Economics and Finance, 44(2), 191-207. http://dx.doi.org/10.1016/j.qref.2003.09.001

Odean, T. (1998). Volume, volatility, price, and profit when all traders are above average. The Journal of Finance, 53(6), 1887-1934. http://dx.doi.org/10.1111/0022-1082.00078

Poterba, J. M., \& Summers, L. H. (1988). Mean reversion in stock prices: Evidence and implications. Journal of Financial Economics, 22(1), 27-59. http://dx.doi.org/10.1016/0304-405X(88)90021-9

Richards, A. J. (1997). Winner-Loser reversals in national stock market indices: Can they be explained? Journal of Finance, 52, 2129-2144. http://dx.doi.org/10.1111/j.1540-6261.1997.tb02755.x

Schlenker, B. R., \& Miller, R. S. (1977). Egocentrism in groups: Self-serving biases or logical information processing? Journal of Personality and Social Psychology, 35, 755-764. http://dx.doi.org/10.1037/0022-3514.35.10.755

Schmeling, M. (2009). Investor sentiment and stock returns: Some international evidence. Journal of Empirical Finance, 16, 394-408. http://dx.doi.org/10.1016/j.jempfin.2009.01.002

Sharpe, W. F. (1964). Capital Asset Prices: A theory of market equilibrium under conditions of risk. Journal of Finance, 19, 425-442. http://dx.doi.org/10.1111/j.1540-6261.1964.tb02865.x

Shefrin, H. (2008). A behavioral approach to asset pricing. Elsevier Academic Press.

Shiller, R. J. (2000). Irrational exuberance. Princeton University Press.

Statman, M., Thorley, S., \& Vorkink, K. (2006). Investor overconfidence and trading volume. Review of Financial Studies, 19(4), 1531-1565. http://dx.doi.org/10.1093/rfs/hhj032

Wang, F. A. (1998). Strategic trading, asymmetric information and heterogeneous prior beliefs. Journal of Financial Markets, 1, 321-352. http://dx.doi.org/10.1016/S1386-4181(97)00007-4

Wolosin, R. J., Sherman, S. J., \& Till, A. (1973). Effects of cooperation and competition on responsibility attribution after success and failure. Journal of Experimental Social Psychology, 9, 220-235. http://dx.doi.org/10.1016/0022-1031(73)90011-5

Zarowin, P. (1990). Size, seasonality, and stock market overreaction. Journal of Financial and quantitative Analysis, 25, 113-125. http://dx.doi.org/10.2307/2330891

\section{Note}

Note 1. We form three portfolios because of the weak number of stocks listed on the Tunis stock market.

\section{Copyrights}

Copyright for this article is retained by the author(s), with first publication rights granted to the journal.

This is an open-access article distributed under the terms and conditions of the Creative Commons Attribution license (http://creativecommons.org/licenses/by/3.0/). 